\author{
食品群間の相関関係 \\ 飯 泉久子, ${ }^{*}$ 細 見 弘, ** 雨 宮 武 彦*** \\ *神戸学院大学栄養学部 $* *$ 神戸大学医学部第二生理 \\ ***済生会兵庫県病院内科

\section{Correlations between Food Groups} \\ Hisako IIZUMI,* Hiroshi HOSOMI,** Takehiko AMEMIYA*** \\ *Faculty of Nutrition, Kobe-Gakuin University, Tarumi-ku, Kobe \\ **Department of Physiology, Division 2, Kobe University \\ School of Medicine, Ikuta-ku, Kobe \\ ***Saiseikai-hyogoken Hospital, Fukiai-ku, Kobe
}

In order to analyze the relation between the geronto-disease and the dietary life it was designed to investigate the structure of food consumption through the interrelationship among food groups. In 1974, the authors collected food intake data on 95 volunteers of Kobe Research Projects on Gerontology.

From the basis of the simple, the partial and the multiple correlation coefficients of which the absolute values were respectively not less than $0.151,0.165$ and 0.416 , a correlation model of the 28 food groups was formed.

The food consumption structure as all or individual sex was compared to the correlation model. The obtained conclusions are as follows; .

(1) The correlation model of the whole samples is characterized by rice and the other seven families, showing an urbanized dietary pattern.

(2) The model for male characterized by (a) the family of dining out, sugars and sweetners, etc. and (b) the family of spirits, soybean products, etc. It is markedly distinct from that for female the later being characterized by (c) the family of pickles, seeds and nuts, dairy products, etc. and (d) the family of dining out, eutrophics, and tea and coffee, etc.

(3) The correlation model is a useful index to analyze a food consumption structure, showing a type of dietary life or a dietary pattern.

(Received January 6, 1977)

老年病の発症と進展におよぽす食生活の影響を，多变 量的に解析する予備的試みとして，第 1 報”に拈いて は, 各食品群摂取量の变動係数と分布型から, 食生活の 集団特性を検討した。

本報告では，摂取食品群間の相関関係を検討し，対象 集団の食物消費構造解析の指標を求めた。

食品群間の相関関保については, 豊川ら²による単相 関関係の詳細な報告がある。著者らは、これに加えて,他 の変量の影響を除去して 2 変量間の関連を評価する偏相 関分析, ならびに一種の変量と残りの他の変量全体との 阑の深さを評価する重相関分析をあわせて検討した。

†ある集団に打ける食物消費構造の多変量解析（第 2 報)

Trial of Multivariate Analysis of Food Consumption Structure (Report 2)

* 个 673 神戸市垂水区伊川谷町有瀬 518

** $\overline{\mathbf{T}} 650$ 神戸市生田区楠町 7-12-1

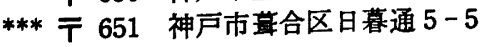

\section{調 查 方 法}

\section{1. 対象ならびに調查方法}

神戸市に居住し，老年病予防長期医学プロシェクトに 所属する，お打むね 40 歳から 60 歳の健常者95名を対象 とし, 昭和 49 年度の食物摄取量調査資料を用いた。調查 方法については，第 1 報に報告した。

\section{2. 解析方法}

1）第 1 報に報告したように75食品項目を24食品群に 分類し，それに食習慣を示す 4 調査項目を加えた 28 項目 を用いた。

2) これら28項目について，各項目間の単相関俰数 $\left(r_{i j}\right)$, 偏相関俰数 $\left(r_{i j \cdot 1}, \cdots, i-1, i+1, \cdots, j-1, j+1, \cdots, n\right)$ to よび各食品群の重相関係数 $\left(R_{i-1,2}, \cdots, i-1, i+1, \cdots, n\right)$ を全 体で，また性ごとに求めた。

3）ついで，正規性を前提としたときの $1 \%$ 有意水準 


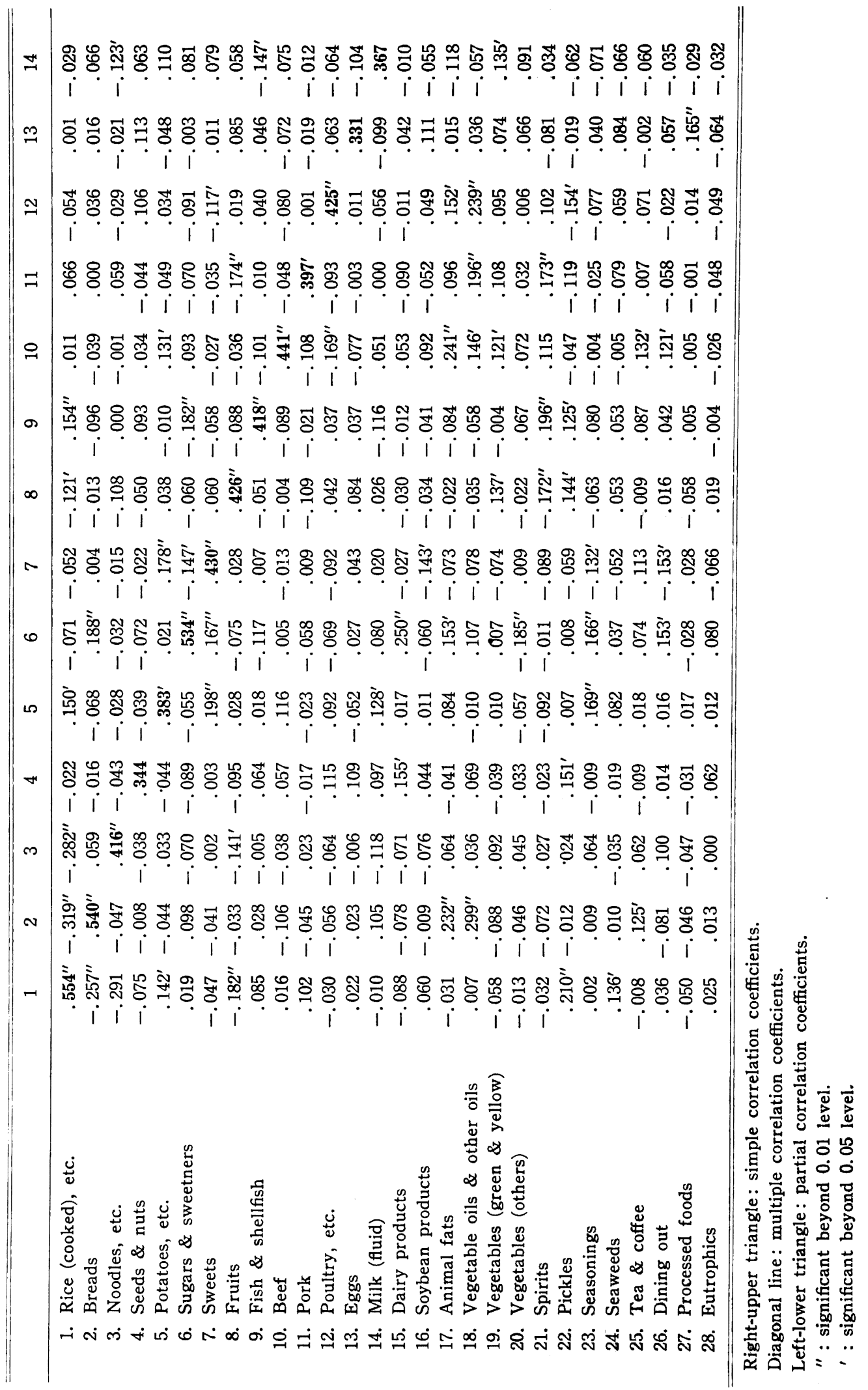




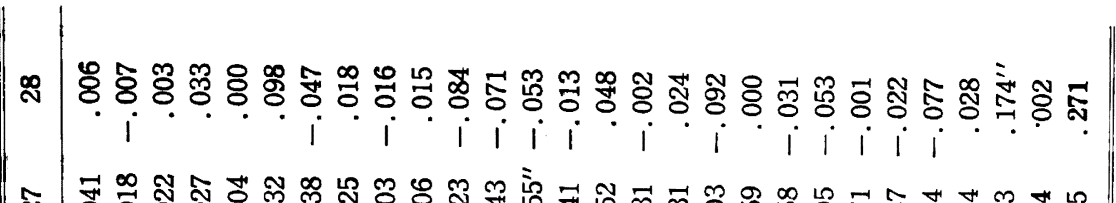

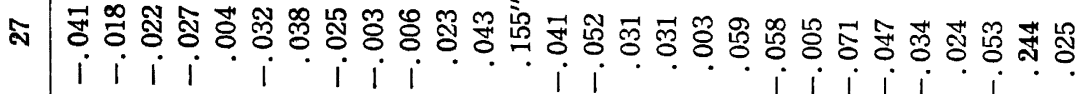

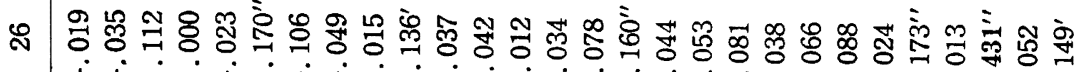

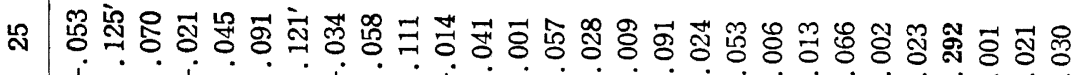

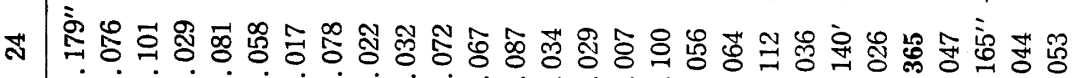
i i i i i i i i i i i i

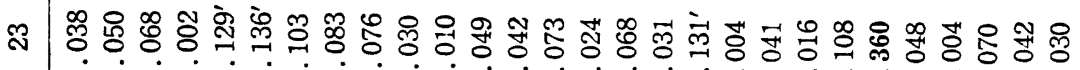

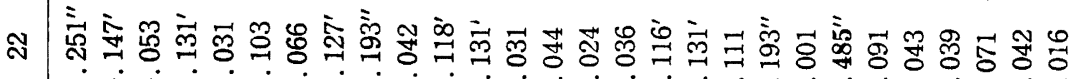

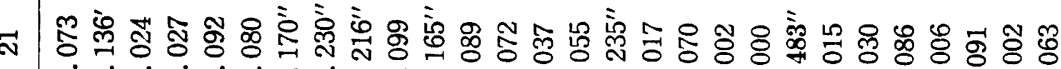

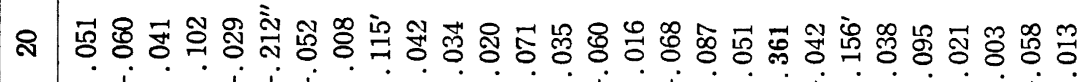

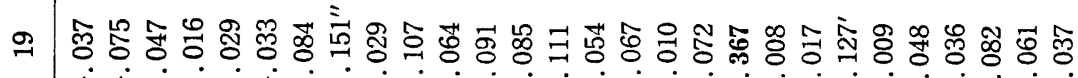

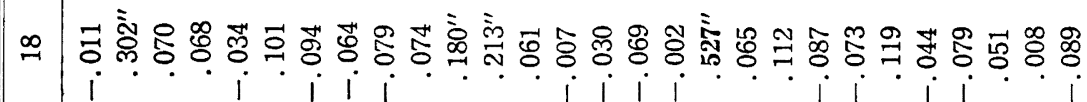

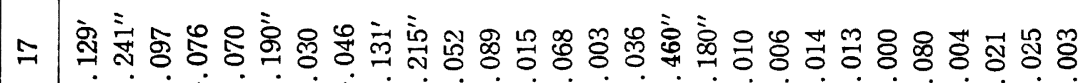

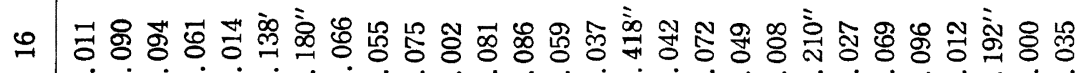

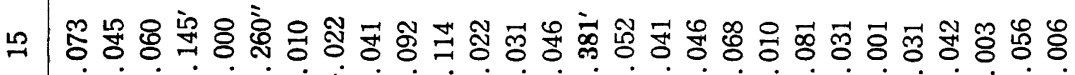
i i i i i i i i i i i i i

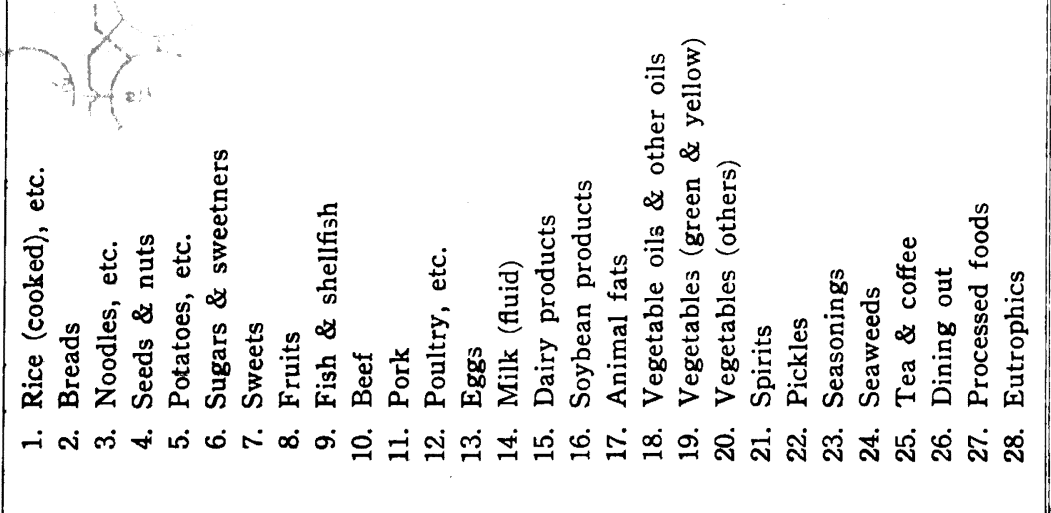


に対応する相関保数の棄却値を用いて, 食品群間の定性 的な関連性を示す相関モデルを作成した。

\section{結果および考察}

Table 1 は, 食品群など28項目間の単相関係数, 偏相 関係数および各食品群の重相関保数を示したものであ る。対角線上に重相関俰数, そして対角線の右上三角に 単相関係数, 左下三角に偏相関係数を配列した。

一食品群間の相関構造を求めるにあたって, まず, 単相 関係数, 偏相関係数㧊よび重相関係数のもつ意味を考察 する。

¿ 重相関保数は, ここでは28項目のうち, 一つの項目 $\left(x_{i}\right)$ と残りの他の 27 項目 $\left(x_{1}, \cdots, x_{i-1}, x_{i+1}, \cdots, x_{27}\right)$ との 間の相関関係である。すなわち, $x_{i}$ が他の 27 項目の一 次結合によって，どの程度説明されるかを表わするので ある。したがって，重相関係数の大きいことは，その項 目と関係する項目，または項目群の存在を示唆している。 つぎ， 2 項目間の相関関係のらち，単相関は，2 項 目の間にどの程度の 1 次関係があるかを示すものであ り,一方, 偏相関は, 他の項目の影響を固定して 2 項目 間の関連をみようとするものである。つまり, 变数 $x_{1}$, $x_{2}, \cdots, x_{n}$ のらち, $x_{i}$ と $x_{j}$ との間の偏相関関係をみよ らとするとき， $x_{i}$ 㧊よび $x_{j}$ におよぼす $x_{i}$ と $x_{j}$ 以外 の変数による影響を固定する。 $x_{i}$ と $x_{j}$ 以外の变数によ る影響を固定するといらことは， $x_{i}$ を $\left(x_{1}, \cdots, x_{i-1}\right.$, $\left.x_{i+1}, \cdots, x_{j-1}, x_{j+1}, \cdots, x_{n}\right)$ の 1 次式で予測し，それを $\hat{x}_{i}$ とし，また， $x_{j} を ，\left(x_{1}, \cdots, x_{i-1}, x_{i+1}, \cdots, x_{j-1}, x_{j+1}, \cdots\right.$, $\left.x_{n}\right)$ の 1 次式で予測し，それを $\hat{x}_{j}$ とするとき $\left(x_{i}-\hat{x}_{i}\right)$ と $\left(x_{j}-\hat{x}_{j}\right)$ との単相関を求めることである。

すなわち, 単相関は, 他の食品群の影響を含んだまま の, そして偏相関は, いわば 2 変数間の純粋3) な相関関 係を表わす。たとえば, Table 1 から米と魚は, 単相関 関係のみ有意である。したがって,これらの関係は，他の 食品群たとえば漬物の影響下で同じ傾向を示したものと 考えられる。そして一方, 牛肉と鶏肉, 油と脂などは, 単相関有意ではないが, 負の偏相関関係有意の食品群で ある。

以上のような観点で, 全体の食品群間の相関関係を基 礎に相関モデルを構成した。

定性的に関係の有無を判定するに当たり, 単相関, 偏 相関および重相関釈数の絶対值が，それぞれ，0.151， 0.165 , および 0.416 以上の值を用いた。これらの值は, 正規性を仮定したときの相関係数の $1 \%$ 有意水準に対応 する䔞却値である。

各項目は, 得られた困が視覚的に簡素となるように配 列した。そして重相関係数の絶対値が 0.416 以上の食品 群を大きな円で表わした。相関が前述の $1 \%$ 水準を越え
るときに，項目間の正の相関関係を実線，負の相威威係 を破線で表わし，相咸の度合いをおおよその線の太さ で表わした。

Fig. 1 は，前述の基準で単相関および重相関を基礎に 相関モデルを構成した。これらの関係は, 複雑に錯綜し ている。これは前述したように他の食品群の影響を含ん だままの見かけの関係である。

Fig. 2 は, 偏相関扎よび重相関関係を基礎に構成し た。この相関モデルは, 整理され, 解积しやすい形とな るが,これは単に数学的な意味において“真” の関保に あり，現実を無視しすぎているかもしれない。

Fig. 3 は, 単相関および偏相関が，いずれも前述の基 準を満たす食品群を選び, 視覚的により簡索な相関モデ ルを構成した。

この相関モデル (Fig. 3) から, 以下に対象集団の摄 取食品群間の相関構造を考察する。

1. 全体の捸取食品群間の相関構造 (Fig. 3)

食品群など28項目間の相関関係のらち, 重相関係数 0.416以上である項目を，その大きさの順に配列すれば， 米, ハンン, 砂糖, 油, 漬物, 酒, 脂, 牛肉, 外食, 菓 子, 果実, 鷄肉, 魚, 大豆製品, めんなどである。これ らの食品群は, (1)米, 漬物。(2)ハン, 油脂, 肉類。(3)酒, 魚, 大豆製品, 豚肉, 果実。(4)砂糖, 乳製品。(5)外食,

\section{Male and Female}

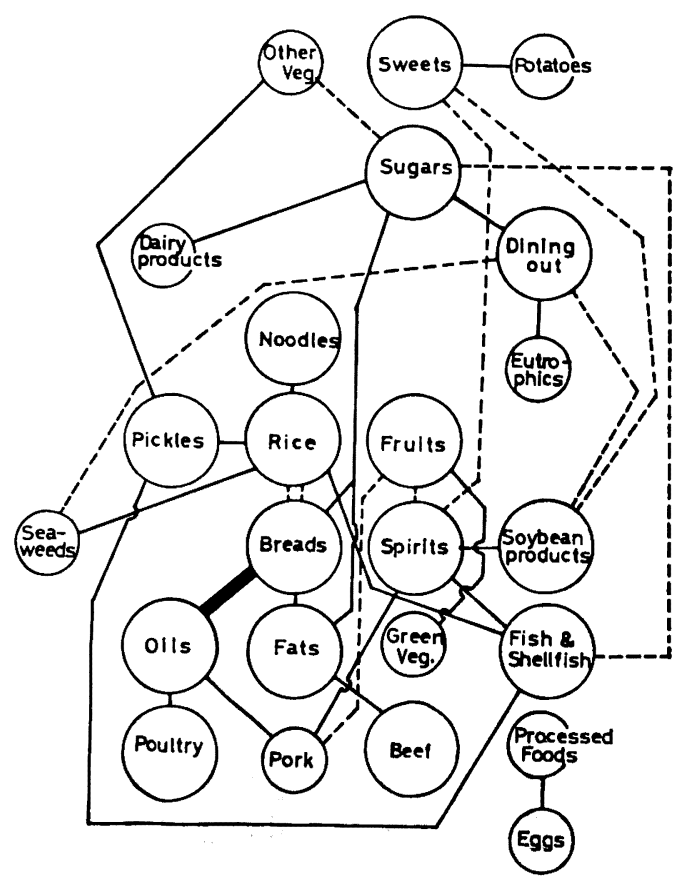

Fig. 1. Correlation model based on the simple correlation coefficients. 


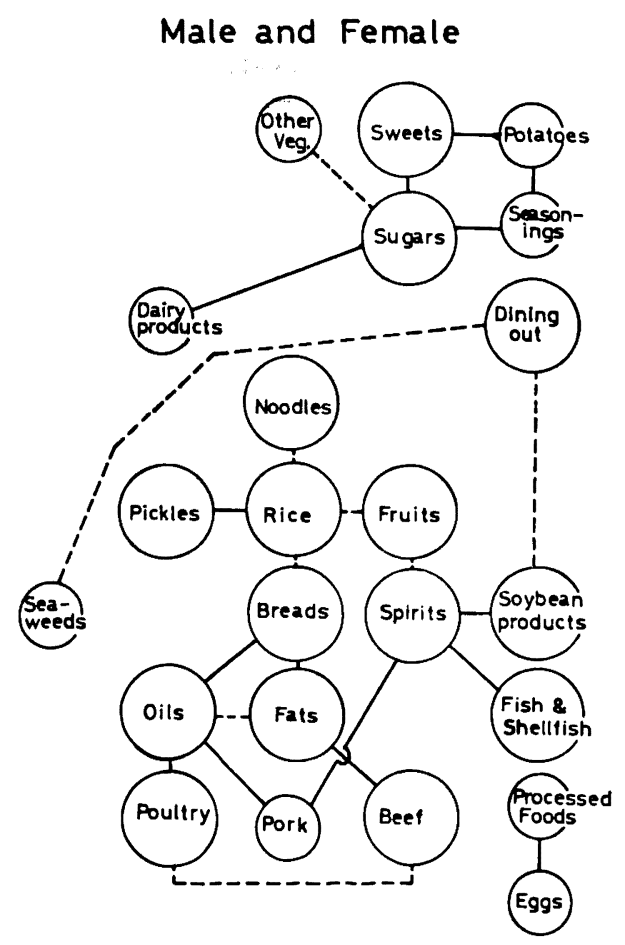

Fig. 2. Correlation model based on the partial correlation coefficients.

大豆製品, 海草。(6)菓子, 芋。(7)めん。(8)調理済食品, 卵などおおよそ8つの「食品族」を形成しており，それ らは，全体構造を特改つけている。

これらの「食品族」のらち, 日本人の食物の中心的位 置を占めてきた，そしてまた大きな値の重相関係数をも つ米は， 2 食品群間の関連に拈いて，めん，パンと負の 相関関係が認められるほか，漬物以外のどの食品群とも 特定のつながりが認められない。しかし, 重相関の值が 大きいことから, 米の多鿒は, その他の項目の摄取量の 多朞に関係している。この相関モデルには, 表現しえな いが，前述したように米と関係する項目，または項目群 の存在が示唆され, 後述のパンの「食品族」とは異なっ た多様性を内包している。

一方, 米についで重相関係数の大きな値をとるパン は, 油脂, 肉のよ5な特定の項目とつながり, $5 \%$ 水準 までとれば, 杠茶・コーヒー, 砂糖, 乳製品とつながる パン食のバターンが羿められる。そして,これらの食品 群は，一般に西欧型の食物といわれている4。

さらに, 酒, 魚, 大豆製品, 豚肉, 果実の関連は, 経 済企画庁の「生活時間の構造分析」5) で報告されている “有職男性は, レストラン, 酒場, 㖵楽施設などで過ご す時間が多い"結果とも一致している。これは,レクリ ×ーションその他都会人特有の欲求充足の行動様式の反 映とも考えられる。なお，生乳, 粶黄色野菜, 種実につ

\section{Male and Female}

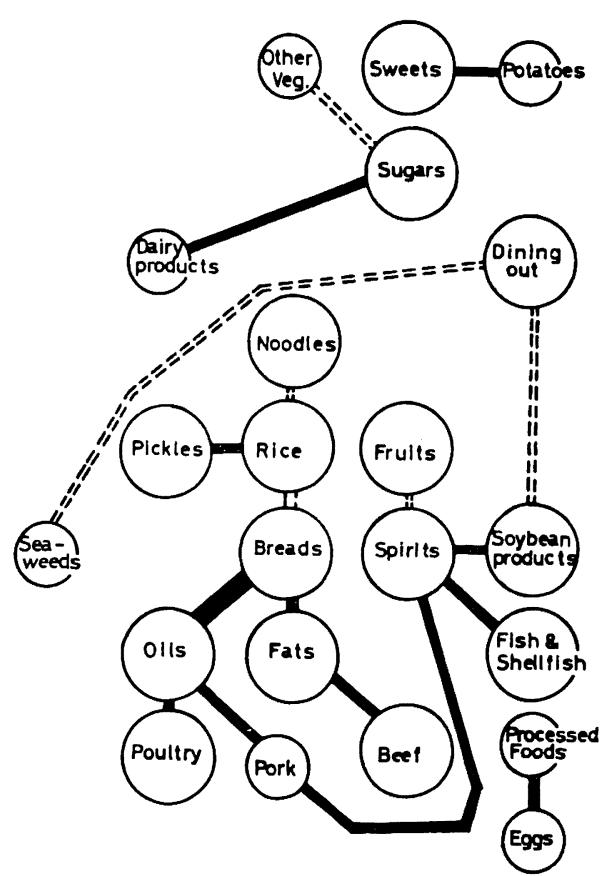

Fig. 3. Correlation model based on the simple and partial correlation coefficients.

This model is constructed by the food groups between which interrelations are significant beyond 0.01 level in both the simple and partial correlation coefficients. The multiple correlation coefficients of the food groups, enclosed with a large circle, is significant beyond 0.01 level.

A solid and broken lines represent a positive and negative correlation coefficients respectively and thickness of a line indicates a level of a correlation coefficients.

いては, 他の食品群との相関関係が弱いので，この罒の どこにも表現されない食品群である。

\section{2. 性別にみた捸取食品群間の相関桡造}

性別にみた摄取食品群間の相関モデルを Fig. 4 に示 す。

Fig. 4 左に示した男性の相関モデルは, Fig. 1 の全 体のそれに比較的類似している。つまり，全体の相関モ デルは, 男性の相関構造を, より多く反映したものであ る。男性に拈いて, 重相関関係有意である項目は, 砂 糖, パン, 牛肉, 油, 脂, 漬物, 米, 緑黄色野菜, 大豆 製品, 外食, 菓子, 調味料であり, 「食品族」は, (1) ン, 油, 豚肉。(2)外食, めん, 砂糖, 乳製品, 菓子。(3)牛 肉, 脂, 緑黄色野菜。(4)米。(5)酒, 大豆製品, 調味料。 (6)卯, 海草となる。

; 一方, Fig. 4 右に示した女性の相関モデルで, 重相関 


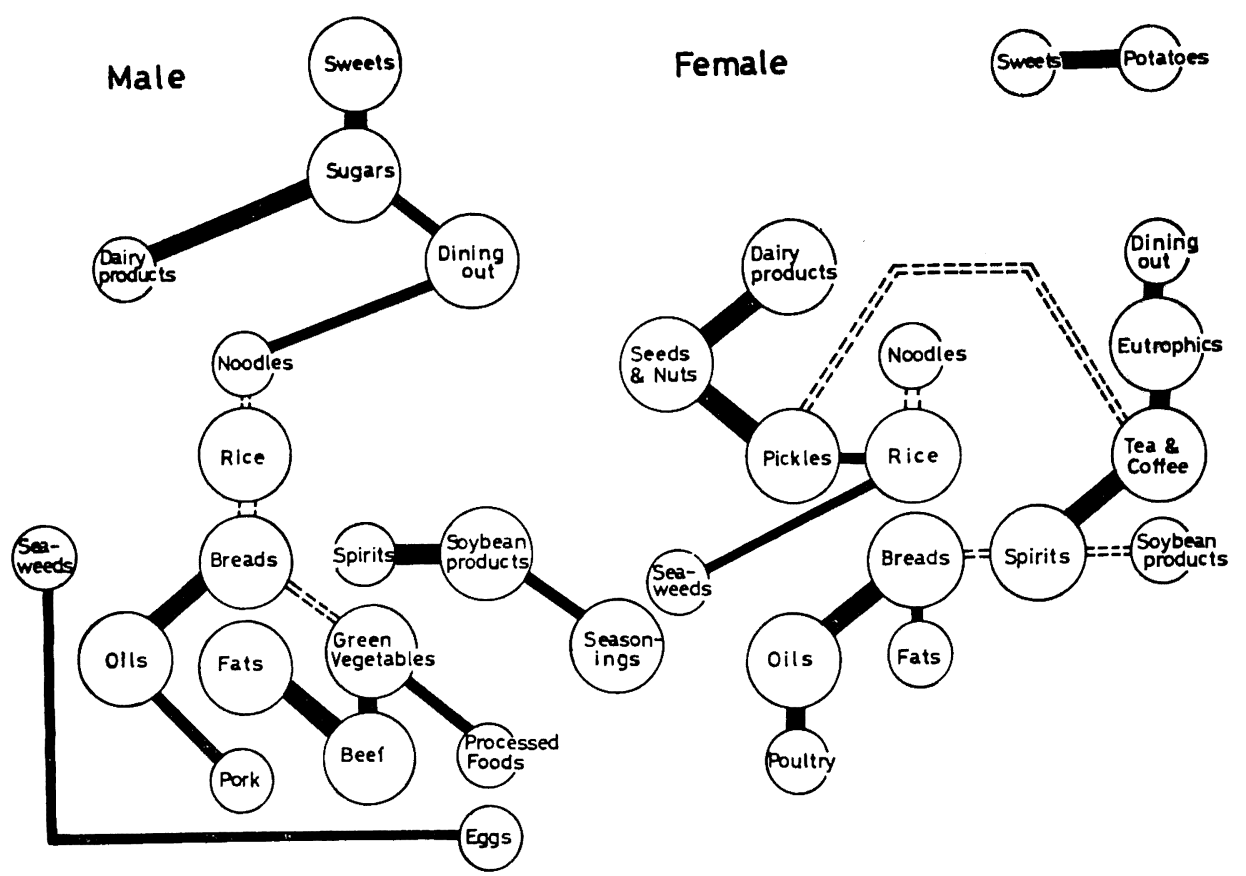

Fig. 4. Correlation model based on the simple and partial correlation coefficients.

関係有意であるものは, 紅茶・コーヒー, 種実, 漬物, ハン, 栄坫剤, 米, 油, 乳製品, 砂糖, 緑黄色野菜, 酒 であり，全体ならびに男性の全体構造と異なっている。 すなわち, 紅茶・コーヒー, 種実, 乳製品が, 重相関係 数の比較的高い食品群として登場し, したがって,「食 品族」は, (1)漬物, 種実, 乳製品, 米, 海草。(2)ハンン, 油, 脂, 鷄肉。(3)紅茶・コーヒー, 栄養剤, 酒, 外食。 (4)菓子, 芓。(5)めんとなる。

以上摂取食品群間の相関構造からみた男性の食生活 は, 外食, めん, 砂糖, 乳製品, 菓子の「食品族」なら び飞酒と大豆製品の「食品族」で特徽づけられ，職場お よびマス・ソサエティの成員としての慣習化された一定 の行動様式がらかがえる。

一方, 女性側の特徽の一つは, 種実, 乳製品, 海草な どのような細流食品群 ${ }^{11}$ 相互の関連にある。このつなが りについての解釈は，困難であり，な険討を要する が，女性の生活の場が主に家庭であることと無関係では ないと思われる。反面, 酒, 紅茶・コーヒ一, 栄湌郕, 外食の関連が女性の特徽として抽出され，都市に生活す る女性の家庭型と外型の二面性がうかがえる。

一般に, 日本人の食生活は，比較的均質なるのとされ ているが，これを相関構造から多面的にみた場合，その 性による差は顕著である。さらに，年龄，家族，個人の 社会的特性などにより層別した場合，多様なタイブの相 関構造が存在することが推測される。そして,これらの
タイプは，食物摄取と環境，疾病などの関連を解析する 上で有用な指標となるであろう。

要約

撰取食品群など28項目間の単相関, 偏相関および重相 関関保が認められるものを基礎に相関モデルを構成し た。

この相関モデルから対象集団である老年病予防長期医 学プロジェクトの成員95名の摄取食品群間の相関構造を 全体扰よび性別に考察した。

1）全体構造は，米，漬物群以下，8つの「食品族」 から構成され，多様な都市の食物消費構造をるつもので あると考えられる。

2）性別にみた摂取食品群間の相関構造は, 男性側の 特徵が外食ならびに酒の「食品族」にあり，女性側の特 徵は, 種実, 乳製品以下, 細流食品群》の組合せにみら れる家庭型の面と酒, 紅茶・コーヒ一, 栄養剤, 外食の

「食品族」にみられる外型との二面性に認められる。

3）相関モデルは，食生活のタイブあるいは食事バタ ーンを表現するものであり, 食物消費構造解析上, 有用 な指標となる。

稿を終わるに臨み、ご討議ここ校睍をいただいた神戸 大学医学部長岡本榇祐教授, ならびに本研究遂行K全面 的にこ協力くださった老年病予防長期医学ブロジット 
の諸氏に深い感謝の意を表します。

なお，本解析は，すへてて神戸大学医学部共同研究館電 算機室を使用して行なったものであり，本研究费の一部 は，昭和49年度兵庫県成人病研究助成金に上るものであ ることを付記します。

\section{文献}

1) 眅泉久子, 細見 弘, 竹崎京子, 雨宮武彦: 栄養 と食糧，30，259（1977）
2）豊川裕之，三宅由子，伊藤雅治：日公有誌，22， 571 (1975)

3）岸根卓郎：理論応用統計学, p. 117 (1975), 養 賢堂（東京）

4) Tillotson, J.L., Kato, H., Nichaman, M.Z., Miller, D.C., Gay, M.L., Johnson, K.G. and Rhoads, G.G.: Amer. J. Clin. Nutr., 26, 177 (1973)

5）程済企画庁国民生活局国民生活調查課：生活時間 の構造分析, p. 45 (1975)，大蔵省印刷局（東京）

(昭和52年 1 月 6 日受理) 